\title{
Journal of the Royal Asiatic Society
}

http://journals.cambridge.org/JRA

Additional services for Journal of the Royal Asiatic Society:

Email alerts: $\underline{\text { Click here }}$

Subscriptions: Click here Commercial reprints: $\underline{\text { Click here }}$ Terms of use : Click here

Journal of the

Royal Asiatic

Society

\section{Notices of Books Description of the Burmese Empire. By Father Sanger-mano, Roman Catholic Missionary. Printed at Rome, 1833; republished at Rangoon, and sold by Messrs. Trübner \& Co.}

R. F. St. A. St. John

Journal of the Royal Asiatic Society / Volume 25 / Issue 04 / October 1893, pp $901-902$

DOI: 10.1017/S0035869X00022681, Published online: 15 March 2011

Link to this article: http://journals.cambridge.org/ abstract S0035869X00022681

How to cite this article:

R. F. St. A. St. John (1893). Journal of the Royal Asiatic

Society, 25, pp 901-902 doi:10.1017/S0035869X00022681

Request Permissions : $\underline{\text { Click here }}$ 
Description of the Burmese Empire. By Father Sangermano, Roman Catholic Missionary. Printed at Rome, 1833 ; republished at Rangoon, and sold by Messrs. Trübner \& Co.

Father Sangermano was sent to Burma in 1782, returned to Italy in 1808 , and died in 1819 . The work above alluded to was left in manuscript, and published after his death. It contains a minute and accurate description of the manners and customs of the people, an abridgment of the annals commonly called "Rāzāwin," an epitome of the Buddhist religion as it exists in Burma, an abstract of the Code of Law called "Dhammathat Shway Myin" (golden rule), and an immense amount of other information. This work was held in such high repute by the late Judicial Commissioner of British Burma, Mr. J. Jardine, I.C.S., that he advised the Government of British Burma to have it reprinted. This was done; but it is much to be regretted that explanatory notes were not added: for the names of persons and places are spelt after an Italian method, which misrepresents the Burmese pronunciation. There are also other matters which require elucidation. For instance, the monks, commonly called "Hpon-gyee" (great glory) by the Burmese, are invariably called by Father Sangermano "Talapoin;" and it has been generally supposed that the word is a corruption of "Talapat," the leaf of the "Talipot" palm, carried by the monks as a screen or fan to bide their faces. The monasteries, called by the Burmese "Kyoung," are called by Father Sangermano "Bao," and the use of these words is now quite unknown. If, however, we bear in mind that Sangermano resided chiefly at Rangoon, where the population is $\mathrm{Mwn}$ (pronounced moon) - - a people with a distinct language and nationality, who were not finally subjugated by the Burmese until 1757, little more than twenty years prior to Sangermano's arrival-we must naturally look for the explanation of these terms in the Mwn or Peguan language. Accordingly, I find that the Peguan word for "monk" is "Tilapoin," or lord of wealth-from Tala "lord," and poin 
"wealth." "Bao" is similarly the Peguan " $B \bar{a}$, a monastery," which they pronounce very long, like $B \vec{a}-a$. Mr. Haswell in his grammar gives "Tee-la-pain" as the proper word to be used in addressing a superior. Again, Sangermano talks of the Judges of the dead as "Jamamen," and it is not easy to recognize the Hindu "Yama" in this disguise; but the word is evidently composed of "Yama" and the Burmese word "min," a ruler. Our old friends the Karens are called Carian; and "Myo-thu-gyee," the headman of a town, remains "Miodighi;" whilst the headman of a village, "Yua-thu-gyee," is utterly unrecognizable in "Ioadighi." In the chapter on natural products, I fail to recognize "santor" and "durcione" amongst fruits, or "gondon" as a tree; but "marione" is the "mayan" plum (Mangifera oppositafolia). A large lizard is called "tala gojà," which is evidently one of the Varans; but I can find no Burmese or Mwn word like it. A little trouble would have made the book a much more valuable one. Many of the inaccuracies are doubtless due to the fact that the author was not himself able to see the first edition through the press; and much credit is due to the original editor that the work was turned out as well as it was.-Ind. Mag. April, 1887.

R. F. Sт. A. St. John.

Midrash Samuet ..... ed. Salomon Buber. Krakau, 1893. 8vo. pp. 142.

Midrash Mischlé ..... ed. S. Buber. Wilna, 1893. 8vo. pp. 112 (1 sh. 6d.).

The homiletic interpretation of the Bible, which commences already with its first translation into Greek, continues down to the twelfth and thirteenth centuries. The legendary biblical lore that we find in Muhamedan and early Christian writings, finds its last source in those ancient homiletic and legendary commentaries known under the name of Midrash. A critical study of this literature 